The Lichenologist 37(6): 467-475 (2005) (C) 2005 The British Lichen Society doi:10.1017/S0024282905900042 Printed in the United Kingdom

\title{
A tribute to Oliver Lathe Gilbert
}

7 September 1936-15 May 2005

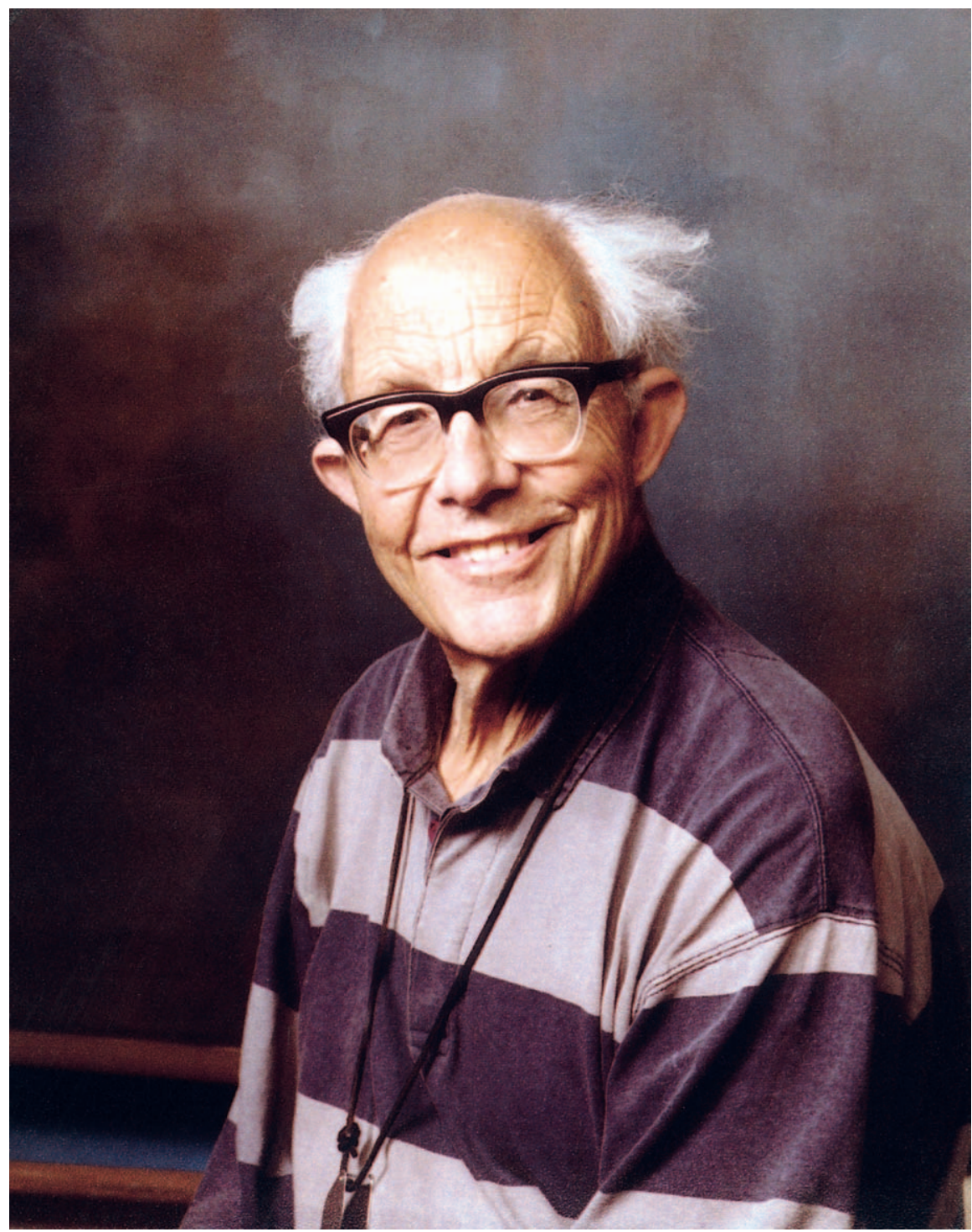


Oliver Gilbert was a pioneer, an outstanding field botanist and inspirational scientist. $\mathrm{He}$ worked in the broad fields of urban and lichen ecology and had almost 40 years of teaching and research experience within universities. Above all he was very approachable, an excellent teacher and fun to be with. Oliver was a leading figure in the British Lichen Society serving as BLS Bulletin Editor (1980-89 except 1987), President (1976-77) and was a frequent Council Member. He was elected an Honorary Member in 1997 and received the prestigious Ursula Duncan Award in January 2004. Oliver had an exceptional ability to find rare and interesting lichens and plant communities that others had overlooked and he constantly challenged conventional wisdom that particular habitats were uninteresting, especially urban habitats. His ecological 'field craft' skills were equally legendary. Passion for field work and British Lichen Society field meetings led him to organize a small grant awards scheme to stimulate others to attend field meetings and to submit their results for publication in the BLS Bulletin.

Oliver Gilbert's interest in natural history was kindled at the age of 4 during the war years when evacuated to Borth y Gest in North Wales where he would collect caterpillars, butterflies and plants to identify. $\mathrm{He}$ was born in Lancaster in 1936, one hour and ten minutes earlier than his twin brother, Christopher, who became a world authority on Chippendale Furniture and was described on his death as the most outstanding furniture historian of his generation. His father, Frank Gilbert, was manager of Durham Chemicals. His mother, Mrs Ruth Gilbert (1908-1984), was a prolific authoress writing under the pen name of Ruth Ainsworth; she wrote a well-known series of children's books about Rufty Tufty Golliwog, and latterly, in the 1970s, authored such titles as 'Three's Company', 'The Mermaid's Tale' and 'The Little Yellow Taxi' as well as countless plays for children's TV and stories for 'Listen with Mother'. Oliver's younger brother, Richard, a former chemistry master at Ampleforth College has written eleven books on mountaineering and hill walking including the now classic 'Big Walks', 'Classic Walks' and 'Wild Walks' and the award winning 'Exploring the Far North West of Scotland'. His uncle was the mycologist Geoffrey Ainsworth, a former Director of the (former) International Mycological Institute and author of several classic texts on mycology. Oliver's literary talents, following a fine family tradition, likewise later excelled.

After the war his family moved to Harpenden where he attended St Georges School. As St Georges did not offer 'A' level Biology, his parents sent him to Watford Grammar School. A botany degree at Exeter University was followed by a DIC in plant pathology at Imperial College London. His first job was as a deputy Warden at Malham Tarn Field Centre in Yorkshire where his passion for walking, fell running and climbing blossomed. After work he would go rock climbing or run effortlessly for hours over the fells. He joined Bingley Harriers Athletics Club and in 1961 was in their small team of 3 runners which won the Yorkshire Three Peaks Race; Oliver's time was an astonishing 3 hours 9 minutes. His winner's medal hangs on a nail in Winterscales Fold, his family's retreat on the slopes of Whernside. Oliver's athletic prowess later proved to be of tremendous value in his field-work.

Oliver joined the staff of Newcastle University as a demonstrator in 1963 and registered for a $\mathrm{PhD}$. He was promoted to Senior Demonstrator in 1965. It was in Newcastle-upon-Tyne that he carried out his pioneering doctoral studies on Biological Indicators of Air Pollution (involving lichens, bryophytes, fungi, terrestrial algae, phanerogams and invertebrates) in which his detailed mapping studies of lichens and bryophytes, as they came under increasing pollution stress, led to the first zone scales which correlated with $\mathrm{SO}_{2}$ levels. A forerunner of the famous Hawksworth \& Rose scale, Oliver's research led to a deeper understanding of how to produce and interpret lichen-air pollution maps. A simplified scale he devised for use by school children was 
successfully used throughout the UK in a National Survey to map 'our mucky air'. Oliver was the first person to recognize that morphological changes in lichens resulting in thallus deformities and stunting are useful bioindicators of air pollution. He analysed native lichens, mosses and transplants (living and dead) for sulphur and fluoride concentrations along transects from point sources. The high contents he recorded near their inner distributional limits, led him to suggest accumulation efficiency as a factor responsible for the acute sensitivity of certain species. He was the first to highlight the importance of $\mathrm{pH}$ in modifying the toxicity of different sulphur species and to realize the role of shelter/exposure when interpreting distribution data. His studies of historical museum collections highlighted their value as indicators of previous environmental conditions. His doctoral research was presented at the first ever European Congress on the Influence of Air Pollution on Plants and Animals held in Wageningen in 1968 and in the same year was awarded his $\mathrm{PhD}$. His interest in lichens continued to grow and his subsequent long term monitoring studies on Lobaria provided the first evidence for the effects of acid rain on UK lichens. In addition to his sulphur dioxide work, he carried out some of the first serious studies into the influence of fluorides and alkaline dust on lichen communities. All large cement manufacturers currently use his lichen scale to monitor dust in their local environment. He continued his interest in air pollution work studying lichen reinvasion during the period of decreasing sulphur dioxide emissions. He coined the term 'lichen dawdlers' for those species which were slow to reinvade on account of their poor dispersal ability.

Oliver Gilbert's contribution to our knowledge of the ecology and taxonomy of UK lichens is unrivalled and encyclopaedic. In parallel to his pollution studies, he instigated pioneering work on the ecology of lichen communities in various parts of Britain. He first prepared, in the North of England, his lichen flora of Northumberland, later extending his interests to the Hebrides and
Scottish Highlands. His modern accounts of the lichen flora of such internationally important sites such as Ben Lawers, Ben Nevis, the Cairngorm Plateau, Caenlochan, St Kilda and Upper Teesdale, were among the major ecological surveys of lichen vegetation to be carried out in the 20th century. There were few habitats he did not personally explore, though he is perhaps best known for his nationwide studies on the ecology of lichens growing on metalliferous spoil, urban wasteland, mountains, chalk grasslands, freshwater habitats and maritime sites. During this work he discovered 55 lichens new to Britain and he described several new taxa. These included Candelariella medians f. steepholmensis Gilbert, O.L. (1981), Lecanora campestris subsp. dolomitica Gilbert, O.L. (1984) and Caloplaca suaedae Gilbert, O.L. \& Coppins (2001). His vast field experience helped him to recognize several lichens as ecological morphs unworthy of formal taxonomic revision, including Leucocarpopsis devensis G. Salisb, the genus being monospecific. During his last decade he undertook national surveys into the lichen flora of neglected habitats such as chalk grasslands, freshwater lakes and rivers and maritime soft cliffs. His work also highlighted the richness of man-made habitats, such as urban wasteland and disused airfields. He also compared the floras of churchyards with those of the villages in which they stand.

Thirty-five years of ecological work was engagingly summarized in his authoritative book 'Lichens', published in the prestigious New Naturalist series in 2000, the first modern account of the lichen ecology of British habitats, all of which had been studied personally. It has been compared by reviewers to Sir Arthur Tansley's classic work on higher plants The British Islands and their Vegetation. An invaluable reference work for both professionals and amateurs, it was a huge success as it sold out within a few months. Oliver wrote more than 150 papers on lichenology and was a major contributor to The Lichen Flora of Great Britain and Ireland, drawing on his vast personal experience. He is also co-author of the Lichen Red 
Data Book for Britain. In 2004 his final book was published: The Lichen Hunters. This is an account of his lichen exploration experiences, in which his enthusiasm for lichens, field-work and love of life shines through every page.

In 1968 Oliver moved to a lectureship in the Department of Landscape Architecture at the University of Sheffield, the first ecologist to be appointed to a Landscape Architecture Department in the country. He was appointed a Reader in Landscape Ecology in 1986, a post he held until his retirement in 1993, then continuing to teach part time until 2000. Throughout his career, Oliver had a heavy teaching load, latterly sharing the running of the Department and playing a leading role in Sheffield University's Environmental Consultancy. $\mathrm{He}$ supervised several PhD students (e.g. Alan Fryday: montane lichens) and stimulated a great many others, through his encyclopaedic knowledge, enthusiasm and great patience; he particularly enjoyed encouraging amateurs. Oliver's lichenological achievements are all the more remarkable as all his lichen research was carried out alongside a university job that involved expertise in a quite different field i.e. landscape science and management. In this area Oliver's approach was to base investigations on long-term observations. He initially focussed on the creation and management of species-rich grassland and the ecology of sown swards in general. He undertook some of the first experimental work on the establishment of flower-rich grassland and provided a scientific framework for the technique that is still valid. He made in-depth studies of other urban habitats such as woodland, walls, construction sites, wasteland and plants growing along the River Don in Sheffield. He discovered 70-year old wild figs growing by water of the Don previously warmed by Sheffield's Bessemer steel furnaces and in 1993 published a fascinating account of how the 'urban common' varies from city to city, depending on climate, geography, and economic and social history. As many landscape architects prefer information to be passed on through lectures and seminars, he wrote up much of this research in a succinct form: as a book entitled The Ecology of Urban Habitats published by Chapman and Hall in 1989. This was extremely well received both in the UK and abroad. Reprinted as a paperback in 1992, it was translated into German in 1994; a Chinese edition is planned. A further book, Habitat Creation and Repair (Oxford University Press) co-authored by Penny Anderson is a definitive guide including discussion of ethics, theory and general principles along with practical details of designing habitats for wildlife. Oliver also carried out major studies on the autecology of Funiperus communis and Dryopteris villarii as well as comprehensive botanical surveys of remote islands.

Oliver was a cornerstone of the British Lichen Society and was especially welcoming to beginners. As editor of the Bulletin he introduced its readership to numerous fascinating topics. Oliver was especially proud that he had led more field meetings than anyone for the British Lichen Society. The field meeting he organized on the Lizard Peninsula with its unusual serpentine flora was a highlight. True to his style, Oliver wasted no time in speedily working through samples, sending the more unusual to specialists in particular groups and rapidly writing up an account for publication in the Lichenologist. He particularly enjoyed organizing small groups of 'adventure lichenologists', employing 'expedition tactics' to explore new or remote sites. He once arranged for a helicopter to drop a team on the top of Ben Nevis. Field meetings with him were always fun and memorable. His latest book, The Lichen Hunters, which is almost an autobiography, gave him great pleasure during a period of failing health which would have killed anyone with a less robust constitution. Even before his book went to press, Oliver had dedicated himself to the revision of The Lichen Flora of Great Britain and Ireland and his death is a severe loss to those who have been working with him on the project. Its timely publication would be a fitting tribute to his scholarship and contribution to British lichenology. 
David Galloway, in a recent book review, described Oliver as 'a gifted and enthralling writer. An author who has the ability and erudition to present a dazzling array of facts in a lively, readable and often memorable form.' Oliver himself had the last word on lichen hunting: "You go to look for lichens and find in addition familiarity, beauty, companionship, laughter and the warmth of friends".

Oliver is survived by his three loving daughters, Tasha, Kate and Emma.

I warmly thank Oliver for his inspiration and for assisting me in my career, his esteemed friendship and for providing me with a list of publications and research summary in March 2002. I am grateful to his brother Richard Gilbert, his daughters and his friends and colleagues Peter Crittenden, Brian Coppins and Vince Giavarini for their helpful comments on drafts and Mark Seaward for comments on the proof.

\section{REFERENCES}

Gilbert, R. \& Purvis, O. W. (2005) Oliver Lathe Gilbert. Obituary. Personal reminiscences of his brother, Richard and William Purvis spoken at his funeral at Sheffield on 20th May 2005. British Lichen Society Bulletin 96: 1-5.

Marren, P. (2005) Oliver Gilbert. Lichen hunter and urban ecologist in the wildlife jungle of Sheffield. The Independent. Wednesday 18th May 2005.

\section{Publications (1963-2005)}

Publications are arranged under the following subject headings:

- Ecology and taxonomy of lichens and bryophytes

- Landscape science and management

- General botany and ecology

\section{Ecology and taxonomy of lichens and bryophytes}

Gilbert, O. L. (1965) Lichens as indicators of air pollution in the Tyne Valley, In Ecology and the Industrial Society (G. T. Goodman, R. W. Edwards \& J. M. Lambert, eds): 35-47. Oxford: Blackwell Scientific Publications.

Gilbert, O. L. (1966) Lichen pathogens on Lecanora conizaeoides Nyl. ex Cromb. Lichenologist 3: 275.

Gilbert, O. L. (1968) Bryophytes as indicators of air pollution in the Tyne Valley. New Phytologist 67: $15-30$.
Gilbert, O. L. (1968) Biological estimation of air pollution. In Plant Pathologist's Pocketbook (Commonwealth Mycological Institute, ed.): 206-207. Kew: Commonwealth Mycological Institute.

Gilbert, O. L. (1969) The effect of $\mathrm{SO}_{2}$ on lichens and bryophytes around Newcastle upon Tyne. In Air Pollution. Proceedings of the First European Congress on the Influence of Air Pollution on Plants and Animals, Wageningen 1968: 223-235. Wageningen: Centre for Agricultural Publishing and Documentation.

Gilbert, O. L. (1970) Further studies on the effect of sulphur dioxide on lichens and bryophytes. New Phytologist 69: 605-627.

Gilbert, O. L. (1970) A biological scale for the estimation of sulphur dioxide pollution. New Phytologist 69: 629-634.

Gilbert, O. L. (1970) Urban bryophyte communities in north-east England. Transactions of the British Bryological Society 13: 306-316.

Gilbert, O. L. (1970) Lichens. In Natural History of the Lake District (G. A. K. Harvey \& J. A. G. Barnes, eds): 72-75. London: Warne.

Gilbert, O. L. (1970) New tasks for lowly plants. New Scientist 46: 288-289.

Gilbert, O. L. (1971) Some indirect effects of air pollution on bark-living invertebrates. Fournal of Applied Ecology 8: 77-84.

Gilbert, O. L. (1971) Studies along the edge of a lichen desert. Lichenologist 5: 11-17.

Gilbert, O. L. (1971) The effect of airborne fluorides on lichens. Lichenologist 5: 26-32.

Gilbert, O. L. (1972) Field meeting in Northumberland. Lichenologist 5: 337-341.

Gilbert, O. L. (1973) The effect of airborne fluorides. In Air Pollution and Lichens (B. W. Ferry, M. S. Baddeley \& D. L. Hawksworth, eds): 176-191. London: Athlone Press of the University of London.

Gilbert, O. L. (1974) Lichens and air pollution. In The Lichens (V. Ahmadjian \& M. E. Hale, eds): 443-472. New York and London: Academic Press.

Gilbert, O. L. (1974) An air pollution survey by school children. Environmental Pollution 6: 175-180.

Gilbert, O. L. (1974) Reindeer grazing in Britain. Lichenologist 6: 165-167.

Gilbert, O. L. (1975) Wildlife Conservation and Lichens. Exeter: Devon Trust for Nature Conservation.

Gilbert, O. L. (1975) Distribution maps of lichens in Britain. Map 19. Solorina saccata (L.) Ach. Lichenologist 7: 181-183.

Gilbert, O. L. (1975) Distribution maps of lichens in Britain. Map 20. Solorina spongiosa (Sm.) Anzi. Lichenologist 7: 184-185.

Gilbert, O. L. (1975) Distribution maps of lichens in Britain. Map 21. Solorina bispora Nyl. Lichenologist 7: 186-188.

Gilbert, O. L. (1975) Distribution maps of lichens in Britain. Map 29. Solorina crocea (L.) Ach. Lichenologist 7: 190-192. 
Gilbert, O. L. (1975) Lichens. In Bedford Purlieus: its History, Ecology and Management (G. F. Peterken \& R. C. Welch, eds): 125-129. (Monks Wood Symposium No. 7.) Huntingdon: Institute of Terrestrial Ecology.

Gilbert, O. L. (1976) An alkaline dust effect on epiphytic lichens. Lichenologist 8: 173-178.

Gilbert, O. L. (1976) The construction, interpretation and use of lichen/air pollution maps. In Proceedings of the Kuopio Meeting on Plant Damages Caused by Air Pollution (L. Karenlampi, ed.): 83-92. Kuopio: University of Kuopio, Finland.

Gilbert, O. L. (1976) A lichen-arthropod community. Lichenologist 8: 96.

Gilbert, O. L. (1977) Lichen conservation in Britain. In Lichen Ecology (M. R. D. Seaward, ed.): 415-436. New York and London: Academic Press.

Gilbert, O. L. (1977) Field meeting at Lancaster. Lichenologist 9: 83-85.

Gilbert, O. L. (1977) Phenotypic plasticity in Cladonia pocillum. Lichenologist 9: 172-173.

Gilbert, O. L. (1978) Fulgensia in the British Isles. Lichenologist 10: 33-45.

Gilbert, O. L., Earland-Bennett, P. \& Coppins, B. J. (1978) Lichens of the sugar limestone refugium in Upper Teesdale. New Phytologist 80: 403-408.

Gilbert, O. L., Watling, R. \& Coppins, B. J. (1979) Lichen ecology on St. Kilda. Lichenologist 11: 191-202.

Gilbert, O. L. \& Coppins, B. J. (1979) Field meeting at Melrose, Roxburghshire. Lichenologist 11: 97101.

Mahandru, M. M. \& Gilbert, O. L. (1979) Norgangaleoidin, a dichlorodepsidone from Lecanora chlarotera. Bryologist 82: 292-295.

Mahandru, M. M. \& Gilbert, O. L. (1979) Chemical studies in Fulgensia: structures of two new chlorodepsidones. Bryologist 82: 302-305.

Coppins, B. J. \& Gilbert, O. L. (1979) George Johnston's lichen herbarium at the R.B.G., Edinburgh: Notes of the Royal Botanic Garden Edinburgh 37: 381-385.

Gilbert, O. L. (1980) Effect of land-use on terricolous lichens. Lichenologist 12: 117-124.

Gilbert, O. L. (1980) A lichen flora of Northumberland. Lichenologist 12: 325-395.

Furness, S. B. \& Gilbert, O. L. (1980) The status of Thamnobryum angustifolium (Holt) Crundw. Fournal of Bryology 11: 139-144.

Gilbert, O. L. (1980) Lichens of the Limb Valley. Sorby Record 19: 64-67.

Coppins, B. J. \& Gilbert, O. L. (1981) Field meeting near Penrith, Cumbria. Lichenologist 13: 191-199.

Gilbert, O. L., Henderson, A. \& James, P.W. (1981) Citrine-green taxa in the genus Candelariella. Lichenologist 13: 249-251.

Gilbert, O. L. \& Mitchell, J. (1981) Rossdhu Park, Dunbartonshire - a major site for epiphytic lichens. Glasgow Naturalist 20: 123-132.

Gilbert, O. L. \& Gibson, P. G. (1981) Lichens on farm roofs. British Lichen Society Bulletin 48: 1-3.
Gilbert, O. L., Fox, B. W. \& Purvis, O. W. (1982) The lichen flora of a high-level limestone-epidiorite outcrop in the Ben Alder Range, Scotland. Lichenologist 14: 165-174.

Gilbert, O. L. (1982) Canary Islands, Tenerife: terricolous lichens of the semi-arid zone. Lichenologist 14: $90-91$.

Gilbert, O. L. \& Lambley, P. W. (1982) Field meeting at Ludlow, Shropshire. Lichenologist 14: 185-188.

Gilbert, O. L. (1983) The lichens of Rhum. Transactions of the Botanical Society of Edinburgh. 44: 141-152.

Gilbert, O. L. (1983) The lichen flora of Derbyshire. Supplement 2. Naturalist 108: 131-137.

Gilbert, O. L. (1984) Lichens of the Magnesian limestone. Lichenologist 16: 31-43.

Gilbert, O. L. (1984) Some effects of disturbance on the lichen flora of oceanic hazel woodland. Lichenologist 16: 21-30.

Gilbert, O. L., Coppins, B. J. \& James, P. W. (1984) Field meeting to Coll and Tiree. Lichenologist 16: 67-79.

Gilbert, O. L. \& Lambley, P. W. (1984) Field meeting at Llangollen, Denbighshire. Lichenologist 16: 63-66.

Gilbert, O. L. (1984) The lichens of Choire Garbh. New Scientist 101: 42-43.

Gilbert, O. L. \& Fox, B. W. (1985) Lichens of high ground in the Cairngorm Mountains of Scotland. Lichenologist 17: 51-66.

Purvis, O. W., Gilbert, O. L. \& James, P. W. (1985) The influence of copper mineralization on Acarospora smaragdula. Lichenologist 17: 111-114.

Gilbert, O. L. (1985) The lichen flora. In The Natural History of the Sheffield Area (D. Whiteley, ed.): 59-67. Sheffield: Sorby Natural History Society.

Gilbert, O. L. (1985) Lichen ecology on Steep Holm. Proceedings of the Bristol Naturalists' Society 44: 27-34.

Gilbert, O. L. \& Fox, B. W. (1986) A comparative account of the lichens occurring on the geologically distinctive mountains Ben Loyal, Ben Hope and Foinaven. Lichenologist 18: 79-94.

Gilbert, O. L. (1986) Field evidence for an acid rain effect on lichens. Environmental Pollution (Series A) 40: 227-231.

Coppins, B. J., Fletcher, A., Gilbert, O. L. \& James, P. W. (1986) Field meeting in Sutherland. Lichenologist 18: 275-285.

Gilbert, O. L. (1986) Review of J. W. Thomson: American Arctic Lichens. Volume 1: Macrolichens. Columbia University Press, New York. 1984. Lichenologist 18: 100-101.

Gilbert, O. L. \& James, P. W. (1987) Field meeting on the Lizard Peninsula, Cornwall. Lichenologist 19: 319-334.

Gilbert, O. L., Coppins, B. J. \& Fox, B. W. (1988) The lichen flora of Ben Lawers. Lichenologist 20: 201-243.

Gilbert, O. L. (1988) Studies on the destruction of Lecanora conizaeoides by the lichenicolous fungus Athelia arachnoidea. Lichenologist 20: 183-190. 
Gilbert, O. L. (1988) Colonisation by Parmelia saxatilis transplanted onto a suburban wall during declining sulphur dioxide pollution. Lichenologist 20: 197-198.

Gilbert, O. L. (1989) Field meeting in the eastern Howgills, Cumbria. Lichenologist 21: 287-291.

Gilbert, O. L. (1989) Lichens and the greenhouse effect. British Lichen Society Bulletin 65: 1-5.

Gilbert, O. L. (1989) Review of K. Broad. Lichens in Southern Woodlands. Forestry Commission Handbook No. 4. Her Majesty's Stationery Office, London. 1989. Lichenologist 21: 396-397.

Gilbert, O. L. (1990) The lichen flora of urban wasteland. Lichenologist 22: 87-101.

Coppins, B. J. \& Gilbert, O. L. (1990) Field meeting in Galloway. Lichenologist 22: 83-190.

Gilbert, O. L. (1991) A successful transplant operation involving Lobaria amplissima. Lichenologist 23: 73-76.

Gilbert, O. L., Fryday, A. J., Giavarini, V. J. \& Coppins, B. J. (1992) The lichen vegetation of the Ben Nevis range. Lichenologist 24: 43-56.

Gilbert, O. L. (1992) Lichen reinvasion with declining air pollution. In Bryophytes and Lichens in a Changing Environment (J. W. Bates \& A. M. Farmer, eds): 158-179. Oxford: Oxford University Press.

Gilbert, O. L. \& Coppins, B. J. (1992) The lichen flora of Caenlochan, Angus. Lichenologist 24: 143-163.

Gilbert, O. L., Fryday, A. M., Giavarini, V. J. \& Coppins, B. J. (1992) The lichen vegetation of high ground in the Ben Nevis range, Scotland. Lichenologist 24: 43-56.

Gilbert, O. L., Orange, A. \& Fletcher, A. (1992) Field meeting in Gower, South Wales. Lichenologist 24: 299-304.

Gilbert, O. L. (1992) Accounts of the following genera (some co-authored): Candelaria, Candelariella, Cryptolechia, Ephebe, Fulgensia, Lemopsis, Petractis, Placynthium, Poeltinula, Polychidium, Porocyphus, Psorotichia, Pyrenopsis, Solorina, Spilonema, Sporastatia, Synalissa. In The Lichen Flora of Great Britain and Ireland (O. W. Purvis, B. J. Coppins, D. L. Hawksworth, P. W. James \& D. M. Moore eds). London: Natural History Museum.

Gilbert, O. L. (1993) The lichens of chalk grassland. Lichenologist 25: 379-414.

Gilbert, O. L. (1993) The lichen flora of DerbyshireSupplement 3. Naturalist 118: 3-8.

Gilbert, O. L. \& Giavarini, V. G. (1993) The lichens of high ground in the English Lake District. Lichenologist 25: 147-164.

Purvis, O. W. \& Gilbert, O. L. (1994) Lichens of the Blair Atholl Limestone. Lichenologist 26: 367-382.

Gilbert, O. L. (1995) The occurrence of lichens with albino fruit bodies and their taxanomic significance. Lichenologist 28: 94-97.

Gilbert, O. L. (1995) The lichen flora of chalk and limestone streams. Lichenologist 28: 145-159.

Gilbert, O. L. (1995) The conservation of chalk grassland lichens. Cryptogamic Botany 5: 232-238.
Gilbert, O. L. \& Fryday, A. M. (1995) The lichen flora of high ground in the West of Ireland. Lichenologist 28: 113-127.

Gilbert, O. L. \& Ardron, P. (1995) New, rare and interesting lichens from North Derbyshire. Sorby Record 30: 48-53.

Gilbert, O. L. (1996) Lichens. In Endangered Wildlife in Derbyshire. The County Red Data Book (T. Elkington and A. Willmot, eds): 15-26. Derby: Derbyshire Wildlife Trust.

Gilbert, O. L. \& Purvis, O. W. (1996) Teloschistes flavicans in Great Britain. Lichenologist 28: 493-506.

Church, J. M., Coppins, B. J., Gilbert, O. L., James, P. W. \& Stewart, N. F. (1996) Red Data Book of Britain and Ireland. Lichens. Vol. 1: Britain. Peterborough: Joint Nature Conservation Committee.

Gilbert, O. L. (1997) The lichens of Ecclesall Woods 1993. In The Natural History of Ecclesall Woods (I. D. Rotherham \& M. Jones, eds): 35-39. Special Publication No. 1. Peak District Journal of Natural History and Archaeology. Wildtrack Publishing: Sheffield Hallam University.

Gilbert, O. L. (1997) Field meeting at Grange-overSands, Lancashire. Lichenologist 29: 483-487.

Gilbert, O. L. \& Giavarini, V. J. (1997) The lichen vegetation of acid watercourses in England. Lichenologist 29: 347-367.

Gilbert, O. L. (1997) Review of N.G. Hodgetts. The Conservation of Lower Plants in Woodland. Joint Nature Conservancy Committee, Peterborough. Lichenologist 29: 395.

Gilbert, O. L. \& McCutcheon, D. E. (1998) Lichen flora of Northumberland: Supplement 1. Naturalist 123: $15-18$.

Gilbert, O. L. \& Smith, E. C. (1998) Red Data Book for Northumberland: Lichens. Transactions of the Natural History Society of Northumbria 38 (2): 273-288.

Gilbert, O. L. (1999) Conserving Calicium corynellum. British Lichen Society Bulletin 85: 19-22.

Gilbert, O. L. (2000) A tribute to Brian William Fox. Lichenologist 32: 103-104.

Gilbert, O. L. (2000) The lichens of disused World War Two airfields. Lichenologist 32: 585-600.

Gilbert, O. L. (2000) Lichens. New Naturalist Series. London: Harper Collins.

Gilbert, O. L. \& Giavarini, V. J. (2000) The lichen vegetation of lake margins in Britain. Lichenologist 32: 365-386.

Gilbert, O. L. (2000) Aquatic lichens. In Lichen Atlas of the British Isles. Fascicle 5. Aquatic Lichens and Cladonia (Part 2) (M. R. D. Seaward, ed.): London: British Lichen Society.

Gilbert, O. L. (2001) The lichen flora of coastal saline lagoons. Lichenologist 33: 409-417.

Gilbert, O. L. (2001) Freshwater habitats. In Lichen Habitat Management (A. Fletcher, P. Wolseley \& R. Woods, eds): 08-1-3. London: British Lichen Society. 
Gilbert, O. L. (2001) Montane habitats. In Lichen Habitat Management (A. Fletcher, P. Wolseley \& R. Woods, eds): 13-1-2. London: British Lichen Society.

Gilbert, O. L. (2001) Species recovery programme: the Breckland rarities and Teloschistes flavicans. In Lichen Habitat Management (A. Fletcher, P. Wolseley \& R. Woods, eds): 19-1-10. London: British Lichen Society.

Gilbert, O. L. (2001) The growth and development of Thelocarpon laureri and Cladonia humilis, and observations on the recovery of Cladonia podetia from simulated grazing. British Lichen Society Bulletin 88: 52-55.

Gilbert, O. L. (2001) Review of F. Dobson. Lichens. An Illustrated Guide to the British and Irish Species, 4th ed. 2000. Slough: Richmond Publishing Co. Lichenologist 33: 368-369.

Gilbert, O. L. \& Henderson, A. (2001) The common names of British lichens. British Lichen Society Bulletin 88: 33-37.

Henderson, A. \& Gilbert, O. L. (2001) Common names of lichens in North America. British Lichen Society Bulletin 89: 38-39.

Gilbert, O. L. (2002) A transplant operation involving Lobaria amplissima; the first twenty years. Lichenologist 34: 267-269.

Gilbert, O. L. (2002) Lichen flora of Devon published. British Lichen Society Bulletin 90: 62-63.

Gilbert, O. L. (2003) The lichen flora of unprotected soft sea cliffs and slopes. Lichenologist 35: 245-254.

Gilbert, O. L. (2003) Stonehenge. British Lichen Society Bulletin 93: 1-4.

Gilbert, O. L. (2003) Review of R. G. Woods \& B. J. Coppins. A Conservation Evaluation of British Lichens. 2003. London: British Lichen Society. Lichenologist 35: 411-412.

Gilbert, O. L. (2004) The phenology of Sarcosagium campestre observed over three years. Lichenologist 36: 159-161.

Gilbert, O. L., Coppins, A. M. \& Coppins, B. J., Giavarini, V. J. \& Woods, R. (2004) What the UK BAP has done for the River Jelly Lichen. British Wildlife 15: 314-318.

Gilbert, O. L. (2004) The Lichen Hunters. Lewes: The Book Guild.

\section{Landscape science and management}

Gilbert, O. L. (1973) Landscape. In Forestry and the Countryside. Peak District National Park Conference: 12-15.

Gilbert, O. L. (1974) An ecologist's view of landscape architects. Landscape Design 106: 13.

Gilbert, O. L. (1974) The place of biologists in landscape architecture. Fournal of Biological Education 8: 70 .

Gilbert, O. L. \& Weddle, A. E. (1974) Site conservation: a new approach. Landscape Design 107: $24-27$.

Gilbert, O. L. (1975) Effects of air pollution on landscape and land use around Norwegian aluminium smelters. Environmental Pollution 8: 113-121.
Gilbert, O. L. (1976) The establishment and subsequent growth of planted trees in polluted atmospheres. In Proceedings of the Kuopio Meeting on Plant Damages Caused by Air Pollution. (L. Karenlampi, ed.): 126-132. Kuopio: University of Kuopio, Finland.

Gilbert, O. L. \& Wathern, P. (1976) Towards the production of extensive Calluna swards. Landscape Design 114: 35.

Gilbert, O. L. (1976) Conference summing up. Small Woods in the Landscape Conference. Peak Park Planning Board: No. 144: 35.

Wathern, P. \& Gilbert, O. L. (1978) Artificial diversification of grassland with native herbs. The fournal of Environmental Management 6: 29-42.

Wathern, P. \& Gilbert, O. L. (1979) The production of grassland on subsoil. The fournal of Environmental Management 8: 269-275.

Gilbert, O. L. (1979) Biological aspects (of water). In Landscape Techniques (A. E. Weddle, ed.): 128-130. Heinemann.

Gilbert, O. L. \& Wathern, P. (1980) The creation of flower-rich swards on mineral workings. Reclamation Review 3: 217-221.

Gilbert, O. L. (1981) Plant communities in an urban environment. Landscape Research 6: 5-7.

Gilbert, O. L. (1982) The management of urban woodland in Sheffield. Ecos 3: 31-34.

Gilbert, O. L. (1982) Turf transplants increase species diversity. Landscape Design 140: 37.

Gilbert, O. L. (1983) The growth of planted trees subject to fumes from brickworks. Environmental Pollution (Series A) 13: 301-310.

Gilbert, O. L. (1983) The ancient lawns at Chatsworth, Derbyshire. Fournal of the Royal Horticultural Society 108: $471-474$.

Gilbert, O. L. (1983) Chatsworth: the Capability Brown lawn and its management. Landscape Design 146: 8 .

Gilbert, O. L. (1983) Review of: R. Bornkamm, J. A Lee and M. R. D. Seaward (eds): Urban Ecology: 2nd European Ecological Symposium Oxford, 1982. Blackwell Scientific Publications. Lichenologist 15: 103-104.

Gilbert, O. L. (1984) New directions, 7. The urban common. Landscape Design 149: 35-36.

Clements, J., Bradley, C. \& Gilbert, O. L. (1984) Early development of vegetation on urban demolition sites in Sheffield, England. Urban Ecology 8: 139-147.

Gilbert, O. L. (1985) A wild flower mix with a short life. Landscape Design 157: 47-49.

Gilbert, O. L. (1985) Environmental effects of airborne fluorides from aluminium smelting at Invergordon, Scotland 1971-1983. Environmental Pollution (Series A) 39: 293-302.

Gilbert, O. L. \& Rotherham, I. D. (1990) The ecology of urban habitats. Applied Geography 10: 239-240.

Gilbert, O. L. (1991) Diversification of an established sward using native herbs; the first nineteen years. Landscape Design 200: 15-16. 
Gilbert, O. L. (1992) The Flowering of the Cities: The Natural Flora of Urban Commons. Peterborough: English Nature.

Gilbert, O. L. (1992) Rooted in Stone: The Natural Flora of Urban Walls. Peterborough: English Nature.

Gilbert, O. L. (1992) The ecology of an urban river. British Wildlife 3: 129-136.

Gilbert, O. L. (1993) Regenerating balsam poplar (Populus candicans Ait.) $\times$ black poplar (P. nigra L.) at a site in Leeds. Watsonia 19: 188-191.

Gilbert, O. L. (1994) Japanese knotweed - what problem? Urban Wildlife News 11: 1-2.

Gilbert, O. L. (1994) Vegetation and soils in urban areas. Fournal of the South-East of England Soils Discussion Group 9: 19-27.

Gilbert, O. L. (1995) Urban commons: a colourful alternative. Enact 3: 10-11.

Gilbert, O. L. (1995) Creating wild-flower meadows: a few problems. Editorial paper. The fournal of Practical Ecology and Conservation 1: 3-6.

Gilbert, O. L. (1996) Retaining trees on construction sites. Arboricultural fournal 20: 39-45.

Gilbert, O. L. \& Bevan, D. (1997) The effect of urbanisation on ancient woods. British Wildlife 8: 213-218.

Gilbert, O. L. (1998) Urban ecological distinctiveness. In Landscapes-Perception, Recognition and Management: Reconciling the Impossible? (M. Jones \& I. D. Rotherham, eds). Conference Proceedings. Landscape Archaeology and Ecology 3: 109-110.

Gilbert, O. L. (1988) Urban scrub. Urban Nature 4: $50-51$.

Gilbert, O. L. (1998) The ancient lawns at Chatsworth. In Naturschutz und Denkmalpflege, 217-220. Hochschulverlag AG an der ETH, Zurich.

Gilbert, O. L. \& Anderson, P. (1998) Habitat Creation and Repair. Oxford: Oxford University Press.

Ardron, P. A., Rotherham, I. D. \& Gilbert, O. L. (1998) Peat-cutting and upland landscapes: case studies from the South Pennines. In LandscapesPerception, Recognition and Management: Reconciling the Impossible? (M. Jones \& I. D. Rotherham, eds). Conference Proceedings. Landscape Archaeology and Ecology 3: 65-69.

Gilbert, O. L. (1998) Entries under 'Anthropocentric' and 'A. N. Other' In The Encyclopedia of Ecology and Environmental Management (P. Calow, ed.): 47. London: Blackwell Science.

Gilbert, O. L. (2003) On hostile ground. Natural History 112: 72-72.

\section{General botany and ecology}

Raistrick, A. \& Gilbert, O. L. (1963) Malham Tarn House, its building materials, their weathering and colonisation by plants. Field Studies 1: 89-115.
Gilbert, O. L. (1963) Grass diseases at Malham Tarn. Naturalist 89: 50.

Roberts, R. H. \& Gilbert, O. L. (1963) The status of Orchis latifolia v. eborensis in Yorkshire. Watsonia 5: 287-293.

Gilbert, O. L. (1966) Dryopteris villarii in Britain. British Fern Gazette 9: 263-268.

Gilbert, O. L. (1969) Biological Flora of the British Isles: Dryopteris villarii. (Bellardi) Woynar. Fournal of Ecology, 58: 301-313.

Gilbert, O. L., Jamison, D., Lister, H. \& Pendlington, J. (1969) Regime of an Afghan Glacier. Fournal of Glaciology 8: 51-65.

Gilbert, O. L., Holligan, P. M. \& Holligan, M. S. (1973) The flora of North Rona 1972. Transactions and Proceedings of the Botanical Society of Edinburgh 42: 43-68.

Gilbert, O. L. \& Wathern, P. (1976) The flora of the Flannan Isles. Transactions and Proceedings of the Botanical Society of Edinburgh 42: 487-503.

Gilbert, O. L. \& Holligan, P. M. (1979) Puccinellia capillaris $\times P$. maritima on North Rona, Outer Hebrides. Watsonia 13: 338-339.

Gilbert, O. L. (1980) Juniper in Upper Teesdale. fournal of Ecology 68: 1013-1024.

Gilbert, O. L. (1983) The wildlife of Britain's wasteland. New Scientist 97: 823-829.

Gilbert, O. L. (1989) The Ecology of Urban Habitats. London: Chapman and Hall.

Gilbert, O. L. (1990) Wild figs by the River Don, Sheffield. Watsonia 18: 84-85.

Gilbert, O. L. (1991) The Ecology of Urban Habitats. London: Chapman and Hall.

Gilbert, O. L. (1994) Städtische Ökosysteme. Stuttgart: Neumarm Verlag Radebeul.

Gilbert, O. L. (1995) Biological Flora of the British Isles: Symphoricarpos albus (L) S. F. Blake. fournal of Ecology 83: 159-166.

Benhouhou, S. S., Dargie, T. C. D. \& Gilbert, O. L. (2001) Vegetation associations in the Great Western erg and the Saoura valley, Algeria Phytocoenologia 31: 311-324.

Benhouhou S. S., Dargie T. C. D. \& Gilbert O. L. (2003) Vegetation associations in the Ougarta Mountains and dayas of the Guir hamada, Algerian Sahara. Fournal of Arid Environments 54: 739-753.

Ardron, P. A. \& Gilbert, O. L. (2005) The myxomycetes of the Sheffield area. Naturalist 130: 13-26.

O. William Purvis

O. W. Purvis: Department of Botany, The Natural History Museum, Cromwell Road, London, SW7 5BD. 